
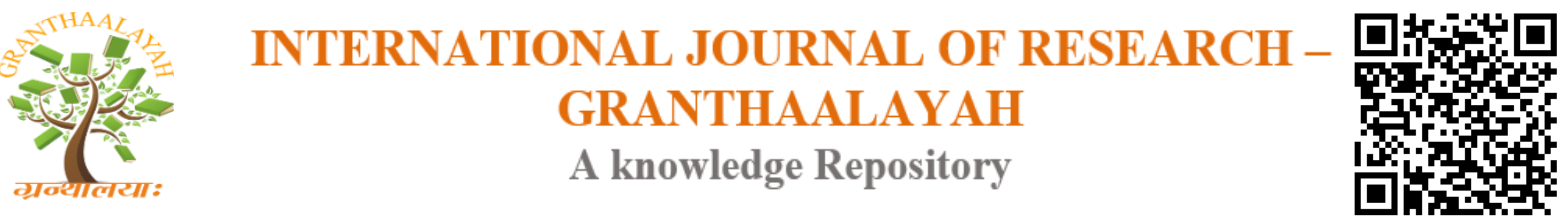

Science

\title{
KNOWLEDGE, ATTITUDES TO, AND UTILIZATION OF THE NATIONAL HEALTH INSURANCE SCHEME (NHIS) AMONG HEALTH WORKERS IN THE UNIVERSITY OF NIGERIA TEACHING HOSPITAL(UNTH), ITUKU-OZALLA, ENUGU STATE, NIGERIA
}

\author{
Ekwuluo Celestine $\mathbf{E}^{1}$, Eluwa Achama $\mathrm{N}^{2}$, Okereke Isaac $\mathbf{C}^{3}$, Orji Somtochukwu B ${ }^{4}$ \\ 1,2,3,4 Department of Community Medicine, College of Medicine, University of Nigeria, Enugu \\ Campus. Enugu State, Nigeria
}

\begin{abstract}
This is a study to determine the knowledge, attitudes to, and utilization of the National Health Insurance Scheme (NHIS) among health workers at the University of Nigeria Teaching Hospital (UNTH), Ituku-Ozalla, and Enugu State, Nigeria. It is a descriptive study. Information was gathered using a closely monitored interviewer-administered questionnaire.

Method: A stratified random sampling method in which 328 questionnaires were satisfactory completed, was carried out in December 2011 at the University of Nigeria, Teaching Hospital, Ituku-Ozalla. The questionnaires used in this study were a combination of both structured closeended questions and unstructured open-ended questions. The data was analyzed using statistical program for social sciences (SPSS) software. Variables explored in our study were aimed at understanding the factors affecting and recommending ways of improving the knowledge, utilization of, and attitude to the National Health Insurance Scheme (NHIS) among health workers at the University of Nigeria Teaching Hospital (UNTH), Ituku-Ozalla, Enugu State, Nigeria,.

Results: $188(57.3 \%)$ of our respondent were females, while $140(42.7 \%)$ were males. There was a $98.2 \%$ awareness among the respondents as against $1.8 \%$ who had not heard of the scheme prior to this research. About $36.3 \%$ of respondents had heard of the scheme from colleagues, $37.3 \%$ from the radio/television, while only $3.7 \%$ had gotten their information about the NHIS from the internet. $63.4 \%$ of the respondents were registered beneficiaries of the NHIS as against $36.6 \%$ who were not registered. An encouraging $70.1 \%$ of the registered respondents had actually used the scheme before. Important to note was that $41.1 \%$ of registered married respondents had actually utilized the scheme while only $39.5 \%$ of the registered single respondents were indeed users. From the research, there is a low patronage of the scheme by doctors as only $41.1 \%$ of the doctors were registered as against $60.3 \%$ of nurses, $100 \%$ of financial officers and $84.2 \%$ of the support workers that were registered.

Conclusion: $65.7 \%$ of the respondent believed that the scheme was not expensive, while only about $16.7 \%$ of the respondents wanted the scheme discontinued. Generally there is a high awareness of the National Health Insurance Scheme. However, the utilization of, and attitudes to the National Health Insurance Scheme are not encouraging. Respondents were optimistic about the scheme as majority felt it should be improved on rather than discontinued. Providing solution
\end{abstract}


to the problems and limitations highlighted in our study will go a long way in improving the health and wellbeing of the health workers and by extension, the entire populace in a country like Nigeria.

Keywords: Knowledge; Health Insurance Scheme; Workers.

Cite This Article: Ekwuluo Celestine E, Eluwa Achama N, Okereke Isaac C, and Orji Somtochukwu B. (2018). "KNOWLEDGE, ATTITUDES TO, AND UTILIZATION OF THE NATIONAL HEALTH INSURANCE SCHEME (NHIS) AMONG HEALTH WORKERS IN THE UNIVERSITY OF NIGERIA TEACHING HOSPITAL(UNTH), ITUKU-OZALLA, ENUGU STATE, NIGERIA." International Journal of Research - Granthaalayah, 6(1), 1-22. https://doi.org/10.29121/granthaalayah.v6.i1.2018.1590.

\section{Introduction}

Against the backdrop of concerted efforts by the United Nations (UN) in drafting a master-plan aimed at the improvement of healthcare delivery in developing countries, member-nations began the institution of several health reforms. These efforts by the UN culminated in the launching of the millennium development goals (MDGs) in the year 2000, of which numbers 4, 5 and 6 focused on this. ${ }^{1}$ However, by the year 2005, Nigeria's health system was still performing far below average even by sub-Saharan standards and was ranked the 197th out of the 200 member states of the United Nations. ${ }^{2}$ A failing healthcare delivery system as evidenced by this low ranking made it imperative for the Nigerian government to take measures at reducing the cost of quality health care and improving accessibility to same for its citizenry.

Access to healthcare is severely limited in Nigeria. ${ }^{3}$ Inability of the consumers to pay for the services as well as healthcare provision that is far from equitable has been identified amongst other factors as responsible for this limitation. ${ }^{4}$ It is for these and other sundry reasons that Nigerians heaved a huge sigh of relief following the inauguration of the National Health Insurance Scheme (NHIS) in June 2005. The vision, mission and operational guidelines of the NHIS are geared towards the sustainable maintenance of the health of the Nigerian populace. A health insurance scheme has been defined as an arrangement in which contributions are made by or on behalf of individuals or groups.

(Members) to a purchasing institution (a fund) which is responsible for purchasing covered services from providers on behalf of the members of the scheme. ${ }^{5}$ It can also be defined as a health insurance that insures a national population for the costs of the healthcare and usually is instituted as a programme of healthcare reforms which may be administered by the public sector, private sector or a combination of both and it is enforced by the law. ${ }^{6}$

Health workers have been defined by the World Health Organization as people engaged in actions whose primary intent is to enhance health. These include people who provide health services-such as doctors, nurses, midwives, pharmacists, laboratory technicians-as well as management and support workers-such as hospital managers, financial officers, cooks, drivers and cleaners. ${ }^{7}$ 
In the operational guidelines of the NHIS released in October 2005, the vision states "A strong dynamic and responsive National Health Insurance Scheme that is totally committed to securing universal coverage and access to adequate and affordable healthcare in order to improve the health status of the Nigerian, especially for those participating in the various programmes/ products of the scheme".8 The mission of the National Health Insurance Scheme reads "Our mission is to facilitate fair-financing of healthcare costs through pooling and judicious utilization of financial resources to provide financial risk protections and cost-burden sharing for people, against high cost of healthcare, through various prepayment programmes/products prior to their falling ill. This is in addition to providing regulatory oversight to Health Maintenance Organizations (HMOs) and participating Healthcare Providers". ${ }^{8}$ The scheme came up with guidelines that direct the health insurance and at this juncture, it will be of utmost importance to point out a few with bearing on the formal sector.

\subsection{Guideline For Public Sector and Organized Private Sector}

\subsubsection{Membership}

Employees of the public and organized private sector employing ten (10) or more persons shall participate in the Programme.

\subsubsection{Contributions}

Contributions are earnings-related. The employer pays $10 \%$ while the employee pays $5 \%$, representing $15 \%$ of the employee's basic salary. However, the employer may decide to pay the entire contribution. In accordance with the existing contractual agreement between employers and employees, especially in the organized private sector, an employer may undertake extra contributions for additional cover to the benefit package.

\subsubsection{Waiting Period}

There shall be a processing (waiting) period of sixty (60) days before a participant can access services.

\subsubsection{Scope of Coverage}

The contributions paid cover healthcare benefits for the employee, a spouse and four (4) biological children below the age of 18 years. More dependents or a child above the age of 18 would be covered on the payment of additional contributions from the principal beneficiary. However children above 18 years who are in tertiary institution will be covered under Tertiary Insurance Scheme.

\subsubsection{Benefit Package}

Healthcare providers under the Scheme shall provide the following benefit package to the contributors:

1) Out-patient care, including necessary consumables; 
2) Prescribed drugs, pharmaceutical care and diagnostic tests as contained in the National Essential Drugs List and Diagnostic Test Lists;

3) Maternity care for up to four (4) live births for every insured contributor/couple in the Formal Sector Programme;

4) Preventive care, including immunization, as it applies in the National Programme on Immunization, health education, family planning, antenatal and post-natal care;

5) Consultation with specialists, such as physicians, pediatricians, obstetricians, gynecologists, general surgeons, orthopedic surgeons, ENT surgeons, dental surgeons, radiologists, psychiatrists, ophthalmologists, physiotherapists, etc.;

6) Hospital care in a standard ward for a stay limited to cumulative 15 days per year. Thereafter, the beneficiary and/or the employer pays. However the primary provider shall pay per diem for bed space for a total 15 days cumulative per year.

7) Eye examination and care, excluding the provision of spectacles and contact lenses;

8) A range of prostheses (limited to artificial limbs produced in Nigeria); and

9) Preventive dental care and pain relief (including consultation, dental health education, amalgam filling, and simple extraction).

Note: All Providers are expected to provide counselling as an integral part of quality care.

\subsubsection{Registration of Employers and Employees}

1) Every employer shall register with the NHIS, upon which a registration number shall be allotted to it by the Scheme.

2) Every employer shall appoint an NHIS-registered Health Maintenance Organization (HMO) of their choice.

3) Every registered employer shall supply the following information to the Scheme and to the appointed HMO:

(i) Name of employer,

(ii) Category of employer (public or private). ${ }^{8}$

Some health policy formulators prescribe insurance as a panacea for accelerated development of the health sector and equitable distribution of health services. With the take-off of such a health insurance scheme, one would have assumed that the healthcare delivery system in Nigeria would gradually find its way out of the woods. But judging from the situation on the ground, the Nigerian healthcare delivery system is still groping in the dark for resuscitation, as the maternal mortality rate (MMR) and the under-five mortality which are major litmus tests for the assessment of healthcare delivery are still unacceptably very high. From a comparative study carried out last year 2010, Nigeria was recorded to have been contributing about $10 \%$ of the global maternal mortality and this has significantly led to the increase in under five mortality. ${ }^{9}$ This quandary that we find ourselves in brings the following questions to the front-burner: Why is the National Health Insurance Scheme which on paper is an admirable venture by government not fulfilling its role, objectives, mission and vision statements? In addition, are there hidden problems and bottlenecks that have not been addressed? The necessity of answering these questions cannot be over-emphasized as in time past the Federal Government of Nigeria had instituted a related scheme. Precisely in 1988, the national health policy was instituted with the main objectives of improving the health status of the people, and allowing Nigerians have 
wholesome, productive, social and economic lives. ${ }^{10}$ It can be asserted that the policy did not see the light of the day as it was bedeviled by numerous setbacks and never fully took-off. To avert the failure of the present National Health Insurance Scheme it is important that the scheme is assessed in all ramifications.

Although there has been extensive work on this pertinent issue, "Awareness and Perception of NHIS Among Radiographers in South-East Nigeria carried out in 2010""11 "The Survey of Knowledge and Opinions of Nigerian Dentists in Lagos State, Nigeria in 2010"12, "An Assessment of Awareness Level of NHIS Among Healthcare Consumers in Oyo State, Nigeria in 2009"4, "Knowledge and Attitude of Civil Servants in Osun State,

South-Western Nigeria towards the NHIS" ${ }^{\prime 13}$, etc., this research is unique because it will also analyze the response of all subgroups of health workers. These mirror the different classes (professionals, degree holders, skilled workers, and non-skilled workers) in society, bearing in mind that people in different social classes may perceive the insurance scheme differently; the more enlightened workers being more health-insurance conscious.

Furthermore, not only will undertaking this study in such a center positively influence the knowledge, attitude and the utilization of NHIS among health workers at UNTH, it will also serve as a veritable platform to identify the problems encountered in the scheme. This will enable the Government to recognize grey areas and to channel its efforts towards improving the effectiveness of the scheme.

\subsection{General Objective}

To determine the knowledge, attitude to, and utilization of the National Health Insurance Scheme (NHIS) among health workers at the University of Nigeria Teaching Hospital (UNTH), Ituku Ozalla, Enugu State, Nigeria.

\subsection{Specific Objectives}

1) To determine the knowledge of the National Health Insurance Scheme (NHIS) among health workers at UNTH, Ituku Ozalla, Enugu.

2) To ascertain the attitude of health workers at UNTH to the NHIS.

3) To determine the level of utilization of the NHIS by the health workers at UNTH, Ituku Ozalla, Enugu State.

4) To determine the influence of socio-demographic profiles on knowledge, attitude and utilization of the National Health Insurance scheme (NHIS) among health workers at UNTH, Ituku Ozalla, Enugu State.

\section{Literature Review}

\subsection{General Review}

Since the enactment in Germany of the mandatory legislation on the "sickness funds "by Emperor Otto Von Bismarck in 1883, different models of health insurance have continued to 
evolve worldwide albeit with the same general principles. ${ }^{14}$ Insurance in its simplest form, is a risk-transfer mechanism in which the insured agrees to make small payments called premium to another party (the insurer), in return for the payment of a large sum (benefit) on the occurrence of a specified event. Health insurance is therefore a social device for pooling health-risks and costs of an exposure unit with a view towards predictability. ${ }^{14}$ In order to provide equitable access to healthcare delivery in Nigeria, the Federal Government introduced the National Health Insurance Scheme (NHIS). The NHIS as a corporate body was set up under Act 35 of 1999, to improve the health of Nigerians at an affordable cost through various prepayment systems and did not fully take off until 2005. It should be noted that the idea of such a scheme was actually conceived in 1962, but was only executed more than three (3) decades later owing to the lack of political will by successive governments both civilian and military. Even though the NHIS has been in existence for some years now, the scheme has been bedeviled by a lot of impediments, and doubts as to its effectiveness have continued to trail the launch of this scheme. One of such doubts is the uncertainty as to whether there is adequate knowledge and capacity to operate an insurance-based health system in an environment where corruption and a general lack of transparency and accountability pervade. ${ }^{15}$

A lot of the studies that have been carried out in the past on the knowledge cum utilization of health insurance have concentrated more on developed economies ${ }^{16,17,18,19,20}$. In recent times however, there has been an upsurge in research on health systems in the developing countries, especially one like Nigeria that continues to perform dismally in World Health Organization's ranking of healthcare systems; ranking 187 th out of 191 member-nations in $2000 .^{21}$

In a study carried out between April and June 2007 in fourteen (14) of the twenty (20) Local Government Areas of Lagos State on factors affecting the usage of NHIS, the following was documented: $72 \%$ of the male respondents made use of the NHIS, while the corresponding figure for the female respondents was $68 \%$. The corresponding percentages of respondents from those sampled are 13, 77 and 62\% for casual workers, civil servants and professionals respectively, while the percentage for others is $67 \% .^{22}$ It is worthy of note that the relatively higher percentage for civil servants is due to the fact that registration for the scheme is mandatory for civil servants. In a related study carried out in South-East Nigeria to ascertain the awareness and perception of the NHIS among professional radiographers, it was discovered that there was $100 \%$ awareness of the existence of the scheme $(n=37)$ with majority having their source of information from seminars in their various hospitals, $43.2 \%(n=16)$. The study also showed that $45.9 \%(n=17)$ have registered for the scheme as against $54.1 \%(n=20)$ not registered. ${ }^{11}$ what is striking here is that the high level of awareness among the radiographers who are health workers has not necessarily translated to high levels of registration with the scheme. This cannot be discussed in isolation as it is a reflection of the attitude of a deep-seated lack of trust in the insurance institution in a developing country like Nigeria.

Historically, primitive forms of insurance had existed in Nigeria long before the advent of modern insurance, the extended family as well as the formation of age-grade associations buttress this point. Despite urbanization and the attendant loosening of family and communal ties, some form of social insurance is still widely practiced by community groups as well as middle-class Nigerians. ${ }^{23}$ An attitude is a learned disposition to behave in a consistently favorable or unfavorable way with respect to a given object. ${ }^{24}$ More succinctly put, attitudes put 
people in a frame of mind of liking or disliking things and are a function of several factors that include demographic and socioeconomic class. In a business context, attitudes affect behaviors and consumers can develop attitudes to any kind of product or service. In a study carried out in 2009 to show the attitudes of Nigerians towards insurance services, the following was documented: respondents with age 45 years and below have a lesser positive attitude towards insurance, while respondents with age group between 56 and 65 years have a more positive attitude towards insurance than others. ${ }^{25}$ This is of course because they are at the tail end of their active-lives and as such are more conscious of retirement and life-after. Gender does not have any statistical significance on Nigerianse ${ }^{\text {e }}$ attitude towards insurance, while marital status has a very significant influence on Nigerians attitude towards insurance. ${ }^{25}$ In line with global trends, the socioeconomic status of respondents affect significantly the attitude of Nigerians to insurance as low household incomes have a lesser positive attitude to insurance than high household income groups.

In a related study of the perception of National Health Insurance Scheme by health care consumers in Oyo State, Nigeria, carried out in 2009, about 65\% of the respondents wanted the programme discontinued. The study revealed that $84.2 \%$ of the respondents were within the 25 55 years age bracket and $52 \%$ of the respondents were males while $48 \%$ were females. ${ }^{4}$

Even though evidence from countries that have institutionalized national health insurance programmes indicates a positive impact on healthcare systems and productivity of labor, there is reluctance to register or a seeming lack of faith in the Scheme by health care users. This may be attributed to the lack of confidence in the programme like previous government programmes or the lack of a social insurance model that will ensure a universal coverage. ${ }^{4}$

Furthermore, the not-too-encouraging perception of the scheme by health care workers who should be in the know can be linked to the inadequate and outdated medical equipment, perennial shortage of medical personnel, lack of awareness and poor funding as evinced by a study on employees "access to the NHIS in Cross-River State. In this study, it was demonstrated that there exists a discrepancy among employees" access to the scheme in Cross-River State, being favorably tilted towards the Federal Government employees and attributable to the State Government's late acceptance of the Scheme. Awareness among civil servants in different ministries, parastatals, departments and agencies where NHIS was accepted and implemented could constitute a major factor why workers at federal level have more access to NHIS facilities than state and local government staff and the self-employed. ${ }^{26}$ This discrepancy can also be attributable to funds, as the heavy cost implication of partnering the NHIS on state governments and private firms may have delayed the take-off of the scheme in states and private companies.

In another related study to assess the knowledge and perception of Nigerian dentists to the NHIS, a survey was conducted amongst 250 dentists employed in private and public dental clinics in Lagos State, Nigeria in 2010. There was a response rate of $89.4 \%$. Most $132(61.1 \%)$ had a fair knowledge of the NHIS, while 22(10.2\%) and 62 (28.7\%) had poor and good knowledge respectively. Majority (70.4\%) viewed the NHIS as a good idea that will succeed if properly implemented. Most (76.6\%) respondents also believed that the scheme will improve access to oral health services, affordability of services (71.4\%), availability of the services $(68.3 \%)$ and recognition of dentistry as a profession $(62.4 \%) .{ }^{12}$ 
From the foregoing, it is clear that the NHIS has recorded some success in the area of awareness especially among Federal Government employees. Although the NHIS aims to reach all Nigerians, the Federal Government took a cue from the experience of other African countries that started the implementation from the informal sector but recorded failures. It therefore began pilot schemes in selected states in each of the six (6) geopolitical zones and restricted cover to the civil servants (formal sector) whose fees could be deducted at source. Also employers in the selected states who had a workforce of 10 or more employees were to ensure mandatory enrolment of their employees in the scheme.

In a recent study to ascertain the success of the NHIS in urban areas of Lagos State, as regards its accessibility, it was found that cost was not the major barrier to access to the NHIS scheme; $11 \%$ was recorded for cost whereas $36 \%$ of the respondents reported not having heard of the NHIS as the reason for not enrolling in the scheme. Another 14\% prefer existing arrangements of out-ofpocket payment. The successes earlier suggested in the area of awareness are indicated in the increase in the percentage of respondents who use the NHIS option from 4.5\% in 2000 and 2003 to $13.6 \%$ in $2004,27.6 \%$ in 2005 and $31.6 \%$ in 2006 . Among those who were not participating in NHIS, about half the total respondents (48.1\%) used public hospitals/dispensaries while $44.3 \%$ reported that they made use of private hospitals. Among the remaining respondents, $2.8 \%$ use drug stores, while $4.8 \%$ alluded to other factors as reasons for not enrolling in the NHIS. ${ }^{27}$ As part of efforts to restructure the almost comatose NHIS scheme, the former minister of health Prof. Eyitayo Lambo set up a ministerial expert committee with a view to giving it a new lease of life. After very extensive survey and research, amongst numerous other recommendations, the committee submitted the following:

In view of the field assessment reports, country experiences of sub-Saharan Africa, SWOT (strength-weakness-opportunities-threats) analysis, and other documentation related to the implementation of the NHIS provided to the committee, the following actions for the repositioning of the scheme proposed:

1) Reposition the National Health Insurance Scheme as a system (rather than as an institution) consisting of a Regulator, Health Insurance Funds, Programmes, and Operators.

2) There should be an omnibus regulator to be known as National Health Insurance Commission (NHIC).

3) There should be a National Health Insurance Fund (NHIF) that will collect and manage Social Health Insurance (SHI) contributions.

4) There should be Private Health Insurance Funds (PHIFs) that will develop and manage health insurance plans.

5) There should be clear split between Insurers (Purchasers) and Providers.

6) Health Maintenance Organizations (HMOs) and Mutual Health Associations (MHAs) should be accredited to function as third party administrators.

7) Providers of healthcare should be accredited from a network of service delivery facilities in both public and private sectors.

8) The NHIC should regulate all Funds and Operators within the scheme to ensure effective pooling and efficient utilization.

9) Remove restrictions and liberalize the establishment of HMOs, PHICs, and MHAs (Community - Based, LGAs, States, Zones, National and Provider - Based). 
10) There should be a deliberate human capital development to produce a new cadre of regulators, fund managers, programme managers, and other healthcare managers to meet the requirements of the new system.

11) NHIF should ensure equity in the implementation of the scheme across the country especially the government funded vulnerable group programmes - presently referred to as the subsidy programmes.

12) The new vulnerable groups ${ }^{\text {ee }}$ programme should be operated by the NHIF and governments at levels should pre-pay the contributions on behalf of these groups.

13) The consultative process with all stakeholders should be revived, to devise appropriate strategies of implementation and engender ownership of the different programmes. Stakeholders should include the civil servants, National Employers Consultative Association (NECA), Nigeria Labour Congress (NLC) and other Workers Unions, National Assembly, State Assemblies, State Executives, LGA Executives, National Council of Health, Professional groups among others.

14) The role of States and LGAs in the design and implementation of the Scheme should be appropriately recognized.

15) The enabling NHIS Act should be revised to take account of these changes.

16) In this repositioning, the new Scheme should take advantage of the existing institutional arrangements - National Primary Health Care Development Agency (NPHCDA), National Programme on Immunization (NPI) National Youths Service Corps (NYSC) among others.

17) Private sector workers should have the option of choosing either the NHIF or any of the PHIFs but they must be covered. ${ }^{28}$

\section{Methodology}

\subsection{Study Area}

The study area of the project was the University of Nigeria Teaching Hospital, Ituku/Ozalla, Enugu state. It was chosen because it is the largest health institution employing the largest population of health workers in the South-Eastern Zone. It is located at 62.70 North and 73.00 East, and approximately $25 \mathrm{~km}$ to the south of Enugu capital city along the Enugu-Port.

Harcourt express road. This Federal Government-run tertiary (Teaching) Hospital is located at Ituku-Ozalla in Nkanu West LGA of Enugu State. The hospital site covers an area of about 200 acres while the entire parcel of land is about 500 hectares (1200 acres). The hospital moved to this permanent site in 2007, and was commissioned by the then president Gen.

Olusegun Obasanjo (rtd.). The hospital section is almost fully completed and equipped. The hospital is mainly divided into wards and clinics. Altogether, there are 41 main departments in the Hospital with three out-posts- comprehensive health centers at Obukpa near Nsukka, Enugu State, Abagana in Njikoka Local Government Area of Anambra State and Isuochi in Abia state. Some of the departments include Accidents \& Emergency, General Outpatient Department (GOPD), Medicine, Surgery, Radiation Medicine, etc. 
The hospital also offers services such as Oncology for Cancer Care, Institute of Child Health (ICH), Heart/Cardiothoracic Centre, Pharmacy, Medical Records, etc.

UNTH has many doctors, residents and consultants, as well as nurses, laboratory technicians, mortuary attendants, students, cleaners, record keepers and other allied staff.

\subsection{Study Design}

The study was a descriptive study of the knowledge, attitudes to, and utilization of the NHIS by health workers in University of Nigeria Teaching Hospital (UNTH). Three hundred and fifty respondents were used in the study, principally staff of the teaching hospital engaged in actions whose primary intent is to enhance health (health workers). The questionnaires used in this study were a combination of both structured close-ended questions and unstructured open-ended questions. All ethical considerations were strictly observed in the collection of data.

\subsection{Approval}

Approval for the study was obtained from the Ethics Committee of UNTH, Enugu.

\subsection{Sample Size Estimation and Sampling}

\subsubsection{Sample Size Estimation}

In order to determine the knowledge, attitudes to and utilization of the NHIS among Health workers in UNTH, the minimum sample size $(\mathrm{N})$ required for the study was

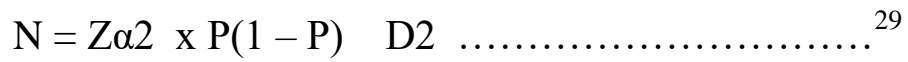

Where $\mathrm{Z} \alpha=$ standard normal deviant using 95\% confidence limit $=1.96$

$\mathrm{D}=$ margin of error tolerated $=0.05$

$\mathrm{P}=$ prevalence of perception (attitude) of 250 Nigerian dentists to the NHIS in Lagos State as a good idea $=70.4 \%=0.704 \ldots \ldots \ldots . . .{ }^{12}$

$\mathrm{N}=1.962 \times(0.704-(0.7042))=3200.052$

Therefore, the minimum total population that was studied was 320 .

In order to accommodate an expected non-response of about $10 \%$ of respondents, the total number of questionnaires actually distributed was three hundred and fifty (350) questionnaires.

\subsubsection{Sampling Frame}

This included all doctors, nurses, pharmacists, physiotherapists, dieticians, medical laboratory scientists, radiographers, hospital managers, financial officers, cooks, drivers, laundry, porters and cleaners in UNTH. 


\subsubsection{Sampling Method}

The sampling method employed was the stratified random sampling. The classification of health workers was based on the WHO definition. ${ }^{7}$ It includes-

- Doctors: House officers, registrars, senior registrars, and consultants

- Nurses: Chief nursing officers, senior nursing officers, nursing officers, midwives, theatre nurses, etc.

- Paramedicals: Medical laboratory scientists, dieticians, radiographers, pharmacists, and physiotherapists.

- Management workers: Hospital managers and financial officers.

- Health support workers: Cleaners, laundry, porters, cooks, and drivers.

The stratified sampling was done proportionately, and a sample ratio was obtained based on the size of each stratum. This enabled us know the number of questionnaires to be assigned to each group.

A random sampling was then done within each group.

\subsection{Data Collection}

The instrument for data collection was an interviewer-administered questionnaire.

\subsection{Data Analysis}

The data obtained after sampling was pooled together for analysis and analyzed using a statistical software programme, the Statistical Program for Social Science (SPSS).

\subsection{Data Presentation}

Our results have been presented in frequency tables, graphs and charts.

\subsection{Ethical Considerations}

1) Ethical clearance was obtained from the Ethics Committee of UNTH, Enugu.

2) Absolute confidentiality of data was maintained during and after the study.

\subsection{Limitations of the Study}

1) There was a lot of bureaucracy involved in obtaining the employee list for the hospital in order to get a sample ratio.

2) Some professionals especially the nurses were reluctant to fill questionnaires as they felt they were always being used for studies.

3) Some support workers needed the questionnaires explained and filled for them as most of them could neither read nor write. 


\section{Results and Discussions}

Table 1:

\section{Socio-demographic data of respondents}

\begin{tabular}{|l|l|l|}
\hline & Frequency & Percentage \\
\hline Age of respondents (in years) & & \\
\hline $20-29$ & 72 & 21.9 \\
\hline $30-39$ & 140 & 42.7 \\
\hline $40-49$ & 74 & 22.6 \\
\hline $50-59$ & 39 & 11.8 \\
\hline $60-69$ & 3 & 1 \\
\hline Sex of respondents & & \\
\hline Male & 140 & 42.7 \\
\hline Female & 188 & 57.3 \\
\hline Marital Status of respondents & & \\
\hline Single & 103 & 42.7 \\
\hline Married & 222 & 67.7 \\
\hline Divorced & 2 & 0.6 \\
\hline Widow & 1 & 0.3 \\
\hline Number of children of respondents & & \\
\hline One Child & 31 & 9.6 \\
\hline Two children & 34 & 10.4 \\
\hline Three children & 34 & 10.4 \\
\hline Four children & 32 & 9.8 \\
\hline Above four children & 50 & 15.2 \\
\hline No child yet & 147 & 44.6 \\
\hline Religion of respondents & & \\
\hline Christianity & 324 & 98.8 \\
\hline Muslim & 4 & 1.2 \\
\hline Occupation of respondents & & \\
\hline Doctor & 91 & 27.7 \\
\hline Nurse & 74 & 22.6 \\
\hline Pharmacist & 6 & 1.8 \\
\hline Dietician & 10 & 3.1 \\
\hline Medical laboratory scientist & 14 & 4.3 \\
\hline Physiotherapist & 2 & 0.6 \\
\hline Health manager & 25 & 7.6 \\
\hline Financial worker & 4 & 1.2 \\
\hline support worker & 95 & 29 \\
\hline & & \\
\hline & & \\
\hline & & \\
\hline
\end{tabular}




\begin{tabular}{|l|l|l|}
\hline Perception of NHIS by respondents & Frequency & Percentage \\
\hline Variables & 26 & 7.9 \\
\hline Takes care of health & 30 & 9.1 \\
\hline Ease access to health care & 35 & 10.7 \\
\hline Sharing of health risk (contribution) & 12 & 3.7 \\
\hline Health insurance for federal civil servant & 108 & 32.9 \\
\hline Subsidized health services & 6 & 1.8 \\
\hline Deception from government & 37 & 11.3 \\
\hline improvement of basic health & 1 & 0.3 \\
\hline Poverty alleviation scheme & 1 & 0.3 \\
\hline Good reception from friendly health workers & 1 & 0.3 \\
\hline Enhancing health seeking behaviour & 5 & 1.5 \\
\hline Free medical services & 66 & 20.1 \\
\hline Don't know & & \\
\hline
\end{tabular}

Table 2:

\begin{tabular}{|c|c|c|}
\hline \multicolumn{3}{|l|}{ Awareness of the NHIS } \\
\hline Variables & Frequency & Percentages \\
\hline Awareness of NHIS by respondents & 322 & 98.2 \\
\hline \multicolumn{3}{|l|}{ When respondents heard of NHIS } \\
\hline less than 1 year ago & 4 & 1.2 \\
\hline $1-5$ years ago & 196 & 60.9 \\
\hline More than 5 years ago & 122 & 37.9 \\
\hline \multicolumn{3}{|l|}{ Source of information about NHIS } \\
\hline Seminar & 93 & 28.9 \\
\hline Radio/Television & 120 & 37.3 \\
\hline Colleagues & 117 & 36.3 \\
\hline Newspaper & 45 & 14 \\
\hline Internet & 12 & 3.7 \\
\hline Others & 23 & 7.1 \\
\hline \multicolumn{3}{|l|}{$\begin{array}{l}\text { Correct knowledge about the NHIS guidelines for } \\
\text { membership \& coverage by respondents }\end{array}$} \\
\hline contributions ( $15 \%$ of salary) & 43 & 13 \\
\hline Wait for 60 days before package can be access & 15 & 4.7 \\
\hline Wait for 1 year before package can be access & 12 & 3.7 \\
\hline coverage includes my spouse, children and I & 17 & 5.3 \\
\hline coverage includes my spouse, my 4 children below 18 and I & 245 & 76.1 \\
\hline Don't know & 9 & 2.8 \\
\hline
\end{tabular}




\begin{tabular}{|l|l|l|}
\hline Awareness of the NHIS (Cont'd) & Frequency & Percentages \\
\hline Variables & & \\
\hline Opinions of respondents concerning the NHIS guidelines & 41 & 12.7 \\
\hline Excited/happy & 136 & 42.2 \\
\hline Satisfied & 97 & 30.1 \\
\hline Indifferent & 48 & 15 \\
\hline Unhappy & & \\
\hline Amount of Salary deduction by employer & 75 & 23.3 \\
\hline Yes & 146 & 45.3 \\
\hline No & 101 & 31.4 \\
\hline Don't know & & \\
\hline $\begin{array}{l}\text { Correct knowledge about the NHIS guidelines for benefit } \\
\text { packages by respondents }\end{array}$ & & \\
\hline No drug & 30 & 9.5 \\
\hline MCH for up to & 103 & 32.1 \\
\hline NPI for all & 65 & 20.2 \\
\hline Admission & 73 & 22.7 \\
\hline Eye examination & 38 & 11.8 \\
\hline Don't know & 12 & 3.7 \\
\hline UTILIZATION OF THE NHIS & & \\
\hline Variables & Frequency & Percentage \\
\hline Registered beneficiaries of the NHIS & 204 & 63.4 \\
\hline Time of registration by respondents & & \\
\hline Less than a year ago & 20 & 9.8 \\
\hline 1 to 5 years & 124 & 60.8 \\
\hline More than 5 years & 60 & 29.4 \\
\hline Utilization of NHIS among the registered respondents at least ones & 143 & 70.1 \\
\hline Frequency of Utilization of the scheme & \multicolumn{2}{|l|}{} \\
\hline Always & 17 & 11.9 \\
\hline Often & 31 & 21.6 \\
\hline Seldom & 40 & 28 \\
\hline Rarely & 55 & 38.5 \\
\hline & \multicolumn{2}{|l|}{} \\
\hline
\end{tabular}

\begin{tabular}{|l|l|l|l|l|}
\hline ATTITUDE TO NHIS & YES & NO \\
\hline Variables & Frequency & Percentage & Frequency & Percentage \\
\hline $\begin{array}{l}\text { improvement in quality of } \\
\text { healthcare by individual benefitting } \\
\text { from the scheme }\end{array}$ & 96 & 47.1 & 108 & 52.9 \\
\hline NHIS is expensive & 70 & 34.3 & 134 & 65.7 \\
\hline Possible hidden charges in NHIS & 56 & 27.5 & 148 & 72.5 \\
\hline Tendency to discontinue with NHIS & 34 & 16.7 & 170 & 83.3 \\
\hline
\end{tabular}




\begin{tabular}{|l|l|l|}
\hline ATTITUDE TO NHIS & Frequency & Percentage \\
\hline Performance score of the NHIS by registered respondents & 18 & 8.8 \\
\hline Excellent & 43 & 21.1 \\
\hline Good & 68 & 33.3 \\
\hline Fair & 38 & 18.6 \\
\hline Poor & 18 & 8.8 \\
\hline Very poor & 19 & 9.3 \\
\hline Don't know & & \\
\hline Problems encountered in using the scheme & 63 & 30.9 \\
\hline Long queues & 35 & 17.2 \\
\hline Poor reception & 47 & 23 \\
\hline expensive drugs & 41 & 20.1 \\
\hline inefficient treatment & 1 & 0.5 \\
\hline unclean environment & 17 & 8.3 \\
\hline Others & & \\
\hline
\end{tabular}

Table 3:

\begin{tabular}{|l|l|l|}
\hline SUGGESTIONS FOR A BETTER NHIS SCHEME BY RESPONDENTS \\
\hline Variables & Frequency & Percentage \\
\hline Better availability & 86 & 42.2 \\
\hline wider coverage & 73 & 35.8 \\
\hline inclusion of expensive drug & 62 & 30.4 \\
\hline elimination of protocols & 43 & 20.6 \\
\hline Better affordability & 41 & 20.1 \\
\hline Better monitoring & 25 & 12.3 \\
\hline reduction percent charges & 24 & 11.8 \\
\hline removal of government bureaucracy & 12 & 5.9 \\
\hline improved Health workers attitude & 16 & 7.6 \\
\hline free services & 5 & 2.5 \\
\hline capacity building on the scheme & 17 & 8.3 \\
\hline
\end{tabular}

Table 4 - 7: Influence of Age of respondents on their Knowledge, Attitude to, and Utilization of the NHIS

Table 4:

\begin{tabular}{|l|l|l|l|}
\hline Age (years) & $\begin{array}{l}\text { Respondents who have } \\
\text { heard about the NHIS }\end{array}$ & $\begin{array}{l}\text { Respondents who } \\
\text { have heard about } \\
\text { the NHIS and are } \\
\text { registered }\end{array}$ & $\begin{array}{l}\text { Respondents who are } \\
\text { registered in the NHIS } \\
\text { and have used its } \\
\text { services before }\end{array}$ \\
\hline $20-29$ & $72(100.0)$ & $28(40.6)$ & $15(53.5)$ \\
$30-39$ & $133(95.0)$ & $83(63.4)$ & $63(75.9)$ \\
$40-49$ & $71(96.0)$ & $57(83.8)$ & $41(71.9)$ \\
$50-59$ & $36(92.3)$ & $34(91.9)$ & $23(67.6)$ \\
$60-69$ & $2(66.7)$ & $2(100.0)$ & $0(0.0)$ \\
\hline
\end{tabular}


Table 5:

\begin{tabular}{|c|c|c|c|c|c|}
\hline & \multicolumn{3}{|c|}{ When did you first hear about NHIS? } & \multirow[t]{2}{*}{ Total } & \multirow{2}{*}{$\begin{array}{l}\text { Chi Square }(P- \\
\text { Value) }\end{array}$} \\
\hline Age(years) & $<1$ yr ago & $1-5$ yrs ago & $>5$ yrs ago & & \\
\hline $20-29$ & $2(1.4)$ & $58(81.7)$ & $12(16.9)$ & 72 & $71.433(0.000)$ \\
\hline $30-39$ & $2(1.5)$ & $86(64.7)$ & $45(33.8)$ & 133 & \\
\hline $40-49$ & $2(2.9)$ & $27(38.5)$ & $42(58.6)$ & 71 & \\
\hline $50-59$ & $0(0.0)$ & $20(56.8)$ & $16(43.2)$ & 36 & \\
\hline $60-69$ & $0(0.0)$ & $0(0.0)$ & $2(100.0)$ & 2 & \\
\hline
\end{tabular}

Table 6:

\begin{tabular}{|l|l|l|l|l|l|}
\hline \multirow{2}{*}{ Age (years) } & \multicolumn{5}{l|}{ How did you hear about NHIS? } \\
\cline { 2 - 6 } & Seminar & Colleague & Radio/TV & Newspaper & Internet \\
\hline $20-29$ & $12(16.4)$ & $23(31.5)$ & $26(35.6)$ & $12(16.4)$ & $4(5)$ \\
$30-39$ & $41(30.1)$ & $69(50.7)$ & $54(39.7)$ & $22(16.2)$ & $6(4.4)$ \\
$40-49$ & $27(37.5)$ & $22(30.6)$ & $29(40.3)$ & $9(12.5)$ & $1(1.4)$ \\
$50-59$ & $14(36.8)$ & $6(15.8)$ & $12(31.6)$ & $3(7.9)$ & $1(2.6)$ \\
$60-69$ & $1(50)$ & $0(0)$ & $1(50.0)$ & $0(0.0)$ & $0(0.0)$ \\
\hline
\end{tabular}

Table 7:

\begin{tabular}{|c|c|c|c|c|c|}
\hline \multirow{2}{*}{ age(years) } & \multicolumn{3}{|c|}{ When did you register? } & \multirow{2}{*}{ Total } & \multirow{2}{*}{$\begin{array}{l}\text { Chi Square } \\
\text { Value })\end{array}$} \\
\hline & $<1$ yr ago & $1-5 y r s$ ago & $>5$ yrs ago & & \\
\hline $20-29$ & $5(17.2)$ & $19(68.7)$ & $4(13.8)$ & 28 & $56.829(0.000)$ \\
\hline $30-39$ & $13(15.7)$ & $55(66.2)$ & $15(18.1)$ & 83 & \\
\hline $40-49$ & $2(3.6)$ & $29(50.0)$ & $26(46.4)$ & 57 & \\
\hline $50-59$ & $0(0.0)$ & $24(68.7)$ & $10(31.3)$ & 34 & \\
\hline $60-69$ & $0(0.0)$ & $1(50.0)$ & $1(50.0)$ & 2 & \\
\hline
\end{tabular}

Table 8 - 10: Influence of Sex of Respondents on their Knowledge, Attitude to, and Utilization of the NHIS

Table 8:

\begin{tabular}{|l|l|l|l|}
\hline Sex & $\begin{array}{l}\text { Respondents who } \\
\text { have heard about } \\
\text { the NHIS }\end{array}$ & $\begin{array}{l}\text { Respondents who } \\
\text { have heard about } \\
\text { the NHIS and are } \\
\text { registered }\end{array}$ & $\begin{array}{l}\text { Respondents who } \\
\text { are registered in the } \\
\text { NHIS and have used } \\
\text { its services before }\end{array}$ \\
\hline Male & $137(97.9)$ & $80(60.2)$ & $56(70.0)$ \\
Female & $184(97.9)$ & $128(70.7)$ & $90(70.3)$ \\
\hline
\end{tabular}

Table 9:

\begin{tabular}{|l|l|l|l|l|l|}
\hline \multirow{2}{*}{ Sex } & \multicolumn{5}{l|}{ How did you hear about NHIS? } \\
\cline { 2 - 6 } & Seminar & Colleague & Radio/TV & Newspaper & Internet \\
\hline Male & $38(27.3)$ & $42(30.2)$ & $63(45.3)$ & $29(20.9)$ & $6(4.3)$ \\
Female & $60(31.7)$ & $82(43.4)$ & $60(31.7)$ & $17(9.0)$ & $6(3.2)$ \\
\hline
\end{tabular}


Table 10:

\begin{tabular}{|l|l|l|l|l|l|}
\hline \multirow{2}{*}{ Sex } & \multicolumn{3}{|l|}{ When did you register for NHIS? } & Total & $\begin{array}{l}\text { Chi Square (P- } \\
\text { Value) }\end{array}$ \\
\cline { 2 - 4 } & $<\mathbf{1}$ yr ago & $\mathbf{1 - 5 y r s}$ ago & $>\mathbf{5}$ yrs ago & & \\
\hline Male & $8(10.1)$ & $52(64.6)$ & $20(25.3)$ & 80 & $4.386(0.495)$ \\
Female & $12(9.4)$ & $78(60.7)$ & $38(29.9)$ & 128 & \\
\hline
\end{tabular}

Table 11:

\begin{tabular}{|l|l|l|}
\hline Religion & $\begin{array}{l}\text { Respondents who have heard } \\
\text { about NHIS }\end{array}$ & $\begin{array}{l}\text { Respondents who have heard about the } \\
\text { NHIS and are registered }\end{array}$ \\
\hline $\begin{array}{l}\text { Christian } \\
\text { Muslim }\end{array}$ & $\begin{array}{l}317(97.8) \\
4(100.0)\end{array}$ & $\begin{array}{l}209(66.4) \\
0(0.0)\end{array}$ \\
\hline
\end{tabular}

Table 12:

\begin{tabular}{|l|l|l|l|l|}
\hline $\begin{array}{l}\text { Marital } \\
\text { Status }\end{array}$ & $\begin{array}{l}\text { Respondents } \\
\text { who have heard } \\
\text { about the NHIS }\end{array}$ & $\begin{array}{l}\text { Respondents who } \\
\text { have heard about } \\
\text { the NHIS and are } \\
\text { registered }\end{array}$ & $\begin{array}{l}\text { Respondents who } \\
\text { are registered in } \\
\text { the NHIS and } \\
\text { have used its } \\
\text { services before }\end{array}$ & $\begin{array}{l}\text { Respondents who } \\
\text { have used the } \\
\text { NHIS services and } \\
\text { think it should be } \\
\text { discontinued }\end{array}$ \\
\hline $\begin{array}{l}\text { Single } \\
\text { Married }\end{array}$ & $102(99.0)$ & $46(47.4)$ & $38(82.6)$ & $15(39.5)$ \\
Divorced & $214(96.4)$ & $160(75.8)$ & $124(77.5)$ & $51(41.1)$ \\
Widowed & $2(100.0)$ & $1(50.0)$ & $0(0.0)$ & $0(0.0)$ \\
$1(100.0)$ & $1(100.0)$ & $100.0)$ \\
\hline
\end{tabular}

Table 13:

\begin{tabular}{|l|l|l|l|l|l|}
\hline \multirow{2}{*}{$\begin{array}{l}\text { Marital } \\
\text { Status }\end{array}$} & \multicolumn{2}{|l|}{ When did you first hear about NHIS? } & Total & $\begin{array}{l}\text { Chi Square (P- } \\
\text { Value) }\end{array}$ \\
\cline { 2 - 4 } Single & $\mathbf{1}$ yr ago & $\mathbf{1 - 5}$ yrs ago & $\mathbf{> 5}$ yrs ago & & $42.978(0.000)$ \\
Married & $3(1.4)$ & $82(79.6)$ & $18(18.4)$ & 102 & \\
Divorced & $0(0.0)$ & $2(100.0)$ & $96(44.9)$ & 214 & \\
Widowed & $0(0.0)$ & $1(100.0)$ & $0(0.0)$ & 2 & \\
\hline
\end{tabular}

Table 14:

\begin{tabular}{|l|l|l|l|l|l|}
\hline How did you hear about NHIS? \\
\hline Marital Status & Seminar & Colleagues & Television & Newspaper & Internet \\
\hline Single & $24(23.8)$ & $34(33.7)$ & $38(37.6)$ & $14(13.9)$ & $3(3.0)$ \\
Married & $73(33.2)$ & $89(40.5)$ & $82(37.3)$ & $30(13.6)$ & $8(3.6)$ \\
Divorced & $0(0.0)$ & $0(0.0)$ & $2(100.0)$ & $2(100.0)$ & $0(0.0)$ \\
Widowed & $1(100.0)$ & $0(0.0)$ & $0(0.0)$ & $1(100.0)$ & $1(100.0)$ \\
\hline
\end{tabular}

Table 15:

\begin{tabular}{|l|l|l|l|l|l|l|}
\hline \multirow{2}{*}{$\begin{array}{l}\text { Marital } \\
\text { Status }\end{array}$} & \multicolumn{2}{l}{$\begin{array}{l}\text { How do you feel about the guideline for } \\
\text { membership, coverage \& benefit packages? }\end{array}$} & Total & $\begin{array}{l}\text { Chi Square } \\
\text { (P-Value) }\end{array}$ \\
\cline { 2 - 5 } & Excited & Satisfied & Indifferent & Unhappy & & \\
\hline Single & $14(10.8)$ & $47(46.2)$ & $34(35.5)$ & $7(7.5)$ & 102 & $16.509(0.057)$ \\
Married & $30(13.2)$ & $87(41.2)$ & $59(27.5)$ & $38(18.1)$ & 214 & \\
\hline
\end{tabular}




\begin{tabular}{|l|l|l|l|l|l|l|}
\hline Divorced & $0(0.0)$ & $0(0.0)$ & $2(100.0)$ & $0(0.0)$ & 2 & \\
Widowed & $0(0.0)$ & $0(0.0)$ & $0(0.0)$ & $1(100.0)$ & 1 & \\
\hline
\end{tabular}

Table 16:

\begin{tabular}{|l|l|l|l|}
\hline $\begin{array}{l}\text { Highest Educational } \\
\text { Qualification }\end{array}$ & $\begin{array}{l}\text { Respondents } \\
\text { who have heard } \\
\text { about the NHIS } \\
\text { and are } \\
\text { registered }\end{array}$ & $\begin{array}{l}\text { Respondents who } \\
\text { are registered in } \\
\text { the NHIS and have } \\
\text { used its services } \\
\text { before }\end{array}$ & $\begin{array}{l}\text { Respondents who have used } \\
\text { the NHIS services and } \\
\text { think the scheme has } \\
\text { improved the quality of } \\
\text { healthcare they receive }\end{array}$ \\
\hline Degree & $129(57.7)$ & $107(82.9)$ & $82(76.6)$ \\
OND & $9(87.5)$ & $7(77.8)$ & $5(71.4)$ \\
NCE & $2(50.0)$ & $0(0.0)$ & $0(0.0)$ \\
Undergraduate & $2(66.7)$ & $2(100.0)$ & $2(100.0)$ \\
SSCE & $50(88.9)$ & $36(72.0)$ & $35(97.2)$ \\
FSLC & $22(90.9)$ & $19(86.4)$ & $19(100.0)$ \\
\hline
\end{tabular}

Table 17:

\begin{tabular}{|c|c|c|c|c|c|}
\hline \multirow{2}{*}{$\begin{array}{l}\text { Highest Educational } \\
\text { Qualification }\end{array}$} & \multicolumn{3}{|c|}{ When did you register? } & \multirow[t]{2}{*}{ Total } & \multirow{2}{*}{$\begin{array}{l}\text { Chi Square (P- } \\
\text { Value) }\end{array}$} \\
\hline & $<1$ yr ago & $1-5$ yrs ago & $>5 \mathrm{yrs}$ ago & & \\
\hline Degree & $17(13.2)$ & $68(52.7)$ & $44(34.1)$ & 129 & $37.155(0.056)$ \\
\hline OND & $0(0.0)$ & $5(57.1)$ & $4(42.9)$ & 9 & \\
\hline $\mathrm{NCE}$ & $0(0.0)$ & $2(100.0)$ & $0(0.0)$ & 2 & \\
\hline Undergraduate & $1(50.0)$ & $1(50.0)$ & $0(0.0)$ & 2 & \\
\hline SSCE & $2(4.3)$ & $42(82.7)$ & $6(13.0)$ & 50 & \\
\hline FSLC & $0(0.0)$ & $16(73.7)$ & $6(26.3)$ & 22 & \\
\hline
\end{tabular}

Table 18:

\begin{tabular}{|c|c|c|c|c|c|c|}
\hline \multirow{2}{*}{$\begin{array}{l}\text { Highest Educational } \\
\text { Qualification }\end{array}$} & \multicolumn{4}{|c|}{ How often do you use the services of NHIS? } & \multirow[t]{2}{*}{ Total } & \multirow{2}{*}{$\begin{array}{l}\text { Chi Square } \\
\text { (P-Value) }\end{array}$} \\
\hline & Always & Often & Seldom & Rarely & & \\
\hline Degree & $9(7.2)$ & $18(16.5)$ & $37(35.1)$ & $43(41.2)$ & 107 & \multirow{5}{*}{$\begin{array}{l}43.695 \\
(0.000)\end{array}$} \\
\hline OND & $0(0.0)$ & $0(0.0)$ & $0(0.0)$ & $7(100.0)$ & 7 & \\
\hline Undergraduate & $2(100.0)$ & $0(0.0)$ & $0(0.0)$ & $0(0.0)$ & 2 & \\
\hline SSCE & $4(9.7)$ & $14(38.7)$ & $7(19.4)$ & $11(32.2)$ & 36 & \\
\hline FSLC & $9(46.4)$ & $4(20.2)$ & $1(6.7)$ & $5(26.7)$ & 19 & \\
\hline
\end{tabular}

Table 19:

\begin{tabular}{|l|l|l|l|l|l|l|}
\hline \multirow{2}{*}{$\begin{array}{l}\text { Highest } \\
\text { Educational } \\
\text { Qualification }\end{array}$} & \multicolumn{2}{|l|}{$\begin{array}{l}\text { How do you feel about the guidelines for } \\
\text { membership, coverage \& benefit packages? }\end{array}$} & Total & \multirow{2}{*}{$\begin{array}{l}\text { Chi Square } \\
\text { (P-Value) }\end{array}$} \\
\cline { 2 - 6 } & Excited & Satisfied & Indifferent & Unhappy & & \\
\hline Degree & $18(8.3)$ & $90(39.4)$ & $87(38.0)$ & $34(14.4)$ & 229 & 52.180 \\
\hline OND & $0(0.0)$ & $5(50.0)$ & $4(40.0)$ & $1(10.0)$ & 10 & \multirow{2}{*}{$0.000)$} \\
\hline NCE & $1(25.0)$ & $3(75.0)$ & $0(0.0)$ & $0(0.0)$ & 4 & \\
\hline Undergraduate & $0(0.0)$ & $3(100.0)$ & $0(0.0)$ & $0(0.0)$ & 3 & \\
\hline SSCE & $9(17.3)$ & $29(51.9)$ & $7(13.5)$ & $10(17.3)$ & 55 & \\
\hline FSLC & $13(50.0)$ & $9(35.0)$ & $0(0.0)$ & $5(15.0)$ & 27 & \\
\hline
\end{tabular}


Table 20:

\begin{tabular}{|c|c|c|c|c|c|c|c|c|}
\hline \multirow{2}{*}{$\begin{array}{l}\text { Highest } \\
\text { Educational } \\
\text { Qualification }\end{array}$} & \multicolumn{6}{|c|}{ How would you score the performance of NHIS? } & \multirow[t]{2}{*}{ Total } & \multirow{2}{*}{$\begin{array}{l}\text { Chi } \\
\text { Square } \\
\text { (P- } \\
\text { Value) }\end{array}$} \\
\hline & Excellent & Good & Fair & Poor & $\begin{array}{l}\text { Very } \\
\text { Poor }\end{array}$ & $\begin{array}{l}\text { Don't } \\
\text { know }\end{array}$ & & \\
\hline Degree & $\begin{array}{c}5 \\
(2.6) \\
\end{array}$ & $\begin{array}{c}48 \\
(20.8)\end{array}$ & $\begin{array}{c}91 \\
(38.5)\end{array}$ & $\begin{array}{c}56 \\
(25.0)\end{array}$ & $\begin{array}{c}27 \\
(12.0)\end{array}$ & $\begin{array}{c}2 \\
(1.0)\end{array}$ & 229 & \multirow[t]{6}{*}{$\begin{array}{l}61.576 \\
(0.000)\end{array}$} \\
\hline OND & $\begin{array}{c}0 \\
(0.0)\end{array}$ & $\begin{array}{c}3 \\
(28.6) \\
\end{array}$ & $\begin{array}{c}5 \\
(42.9) \\
\end{array}$ & $\begin{array}{c}1 \\
(14.3)\end{array}$ & $\begin{array}{c}1 \\
(14.3)\end{array}$ & $\begin{array}{c}0 \\
(0.0)\end{array}$ & 10 & \\
\hline $\mathrm{NCE}$ & $\begin{array}{c}0 \\
(0.0)\end{array}$ & $\begin{array}{c}0 \\
(0.0)\end{array}$ & $\begin{array}{c}1 \\
(25.0)\end{array}$ & $\begin{array}{c}3 \\
(75.0)\end{array}$ & $\begin{array}{c}0 \\
(0.0)\end{array}$ & $\begin{array}{c}0 \\
(0.0)\end{array}$ & 4 & \\
\hline Undergraduate & $\begin{array}{c}0 \\
(0.0)\end{array}$ & $\begin{array}{c}3 \\
(100.0)\end{array}$ & $\begin{array}{c}0 \\
(0.0)\end{array}$ & $\begin{array}{c}0 \\
(0.0)\end{array}$ & $\begin{array}{c}0 \\
(0.0)\end{array}$ & $0(0.0)$ & 3 & \\
\hline SSCE & $\begin{array}{c}9 \\
(17.4) \\
\end{array}$ & $\begin{array}{c}15 \\
(28.3)\end{array}$ & $\begin{array}{c}23 \\
(41.3) \\
\end{array}$ & $\begin{array}{c}4 \\
(6.5) \\
\end{array}$ & $\begin{array}{c}4 \\
(6.5) \\
\end{array}$ & $\begin{array}{c}0 \\
(0.0) \\
\end{array}$ & 55 & \\
\hline FSLC & $\begin{array}{c}10 \\
(37.5)\end{array}$ & $\begin{array}{c}8 \\
(31.3)\end{array}$ & $\begin{array}{c}2 \\
(6.3)\end{array}$ & $\begin{array}{c}5 \\
(18.8)\end{array}$ & $\begin{array}{c}2 \\
(6.3)\end{array}$ & $\begin{array}{c}0 \\
(0.0)\end{array}$ & 27 & \\
\hline
\end{tabular}

Table 21 - 24: Influence of Occupation of Respondents on their Knowledge, Attitude to and Utilization of the NHIS

Table 21:

\begin{tabular}{|l|l|l|l|}
\hline Occupation & $\begin{array}{l}\text { Respondents } \\
\text { who have heard } \\
\text { about the NHIS }\end{array}$ & $\begin{array}{l}\text { Respondents who have } \\
\text { heard about the NHIS } \\
\text { and are registered }\end{array}$ & $\begin{array}{l}\text { Respondents who are } \\
\text { registered in the NHIS } \\
\text { and have used its } \\
\text { services before }\end{array}$ \\
\hline Doctor & $90(98.9)$ & $37(41.1)$ & $22(59.5)$ \\
Nurse & $73(98.7)$ & $44(60.3)$ & $32(72.7)$ \\
Pharmacist & $6(100)$ & $4(66.7)$ & $1(25.0)$ \\
Dietician & $9(90)$ & $7(77.8)$ & $4(40)$ \\
Medical lab scientist & $13(92.9)$ & $9(69.2)$ & $7(57.1)$ \\
Physiotherapist & $2(100)$ & $1(50)$ & $0(0.0)$ \\
Radiographer & $6(85.7)$ & $2(33.3)$ & $1(50.0)$ \\
Health manager & $25(100)$ & $20(80)$ & $17(85.0)$ \\
Financial officer & $4(100)$ & $4(100)$ & $1(25.0)$ \\
Support worker & $95(100)$ & $80(84.2)$ & $55(68.8)$ \\
\hline
\end{tabular}

Table 22:

\begin{tabular}{|l|l|l|l|l|l|}
\hline \multirow{2}{*}{ Occupation } & \multicolumn{6}{l}{ How did you hear about NHIS? } \\
\cline { 2 - 6 } & Seminar & Colleagues & Radio/Television & Newspaper & Internet \\
\hline Doctor & $25(27.5)$ & $38(41.8)$ & $42(46.2)$ & $42(46.2)$ & $4(4.4)$ \\
Nurse & $27(36.5)$ & $27(36.5)$ & $30(40.5)$ & $30(40.5)$ & $4(4.1)$ \\
Pharmacist & $1(16.7)$ & $1(16.7)$ & $2(33.3)$ & $2(33.3)$ & $0(0.0)$ \\
Dietician & $2(22.3)$ & $4(44.5)$ & $3(33.3)$ & $3(33.3)$ & $0(0.0)$ \\
Medical lab scientist & $5(35.7)$ & $5(35.7)$ & $5(35.7)$ & $5(35.7)$ & $1(7.1)$ \\
Physiotherapist & $0(0.0)$ & $0(0.0)$ & $1(50.0)$ & $1(50.0)$ & $0(0.0)$ \\
Radiographer & $2(28.6)$ & $2(33.3)$ & $2(42.9)$ & $2(42.9)$ & $0(0.0)$ \\
\hline
\end{tabular}




\begin{tabular}{|l|l|l|l|l|l|}
\hline Health manager & $6(24.0)$ & $10(40.0)$ & $7(28.0)$ & $7(28.0)$ & $1(4.0)$ \\
Financial officer & $1(25.0)$ & $2(50.0)$ & $2(50.0)$ & $2(50.0)$ & $2(50.0)$ \\
Support worker & $25(26.3)$ & $27(28.4)$ & $28(29.5)$ & $28(29.5)$ & $1(1.1)$ \\
\hline
\end{tabular}

Table 23:

\begin{tabular}{|l|l|l|l|l|}
\hline \multirow{2}{*}{ Occupation } & \multicolumn{3}{|l|}{ Registered respondents who USE NHIS services } \\
\cline { 2 - 5 } & $\begin{array}{l}\text { Respondents } \\
\text { who think NHIS } \\
\text { has improved } \\
\text { the quality of } \\
\text { healthcare they } \\
\text { receive }\end{array}$ & $\begin{array}{l}\text { Respondents } \\
\text { who think } \\
\text { the NHIS } \\
\text { scheme is } \\
\text { expensive }\end{array}$ & $\begin{array}{l}\text { Respondents } \\
\text { who think } \\
\text { there are } \\
\text { hidden charges }\end{array}$ & $\begin{array}{l}\text { Respondents } \\
\text { who think the } \\
\text { NHIS should be } \\
\text { discontinued }\end{array}$ \\
\hline Doctor & $11(50.0)$ & $6(27.3)$ & $8(36.4)$ & $2(9.1)$ \\
Nurse & $12(60.0)$ & $13(40.6)$ & $8(25.0)$ & $7(21.9)$ \\
Pharmacist & $0(0.0)$ & $0(0.0)$ & $0(0.0)$ & $0(0.0)$ \\
Dietician & $2(50.0)$ & $1(25.0)$ & $0(0.0)$ & $1(25.0)$ \\
Medical lab scientist & $5(71.4)$ & $1(14.3)$ & $0(0.0)$ & $0(0.0)$ \\
Radiographer & $0(0.0)$ & $1(100.0)$ & $1(100.0)$ & $0(0.0)$ \\
Health manager & $11(64.7)$ & $8(47.1)$ & $7(41.2)$ & $5(29.4)$ \\
Financial officer & $0(0.0)$ & $1(100.0)$ & $1(100.0)$ & $1(100.0)$ \\
Support worker & $31(56.4)$ & $21(38.2)$ & $19(34.5)$ & $7(12.7)$ \\
\hline
\end{tabular}

Table 24:

\begin{tabular}{|l|l|l|l|l|l|}
\hline \multirow{2}{*}{ Occupation } & \multicolumn{4}{|l|}{ How often do you use the services of this Scheme? } & \multirow{2}{*}{ Total } \\
\cline { 2 - 5 } & Always & Often & Seldom & Rarely & \\
\hline Doctor & $0(0.0)$ & $4(18.2)$ & $12(54.5)$ & $6(27.3)$ & 22 \\
\hline Nurse & $3(9.4)$ & $4(12.5)$ & $14(43.8)$ & $11(34.3)$ & 32 \\
\hline Pharmacist & $0(0.0)$ & $0(0.0)$ & $0(0.0)$ & $1(100.0)$ & 1 \\
\hline Dietician & $0(0.0)$ & $1(25.0)$ & $1(25.0)$ & $2(50.0)$ & 4 \\
\hline Medical lab scientist & $1(14.3)$ & $2(28.6)$ & $1(14.3)$ & $3(42.9)$ & 7 \\
\hline Radiographer & $0(0.0)$ & $0(0.0)$ & $1(100.0)$ & $0(0.0)$ & 1 \\
\hline Health manager & $4(23.5)$ & $4(23.5)$ & $0(0.0)$ & $9(53.0)$ & 17 \\
\hline Financial officer & $0(0.0)$ & $1(100.0)$ & $0(0.0)$ & $0(0.0)$ & 1 \\
\hline Support worker & $9(16.5)$ & $16(29.0)$ & $11(2.0)$ & $19(34.5)$ & 55 \\
\hline
\end{tabular}

\section{Conclusions}

The research shows that there is a high level of awareness of the existence of the National Health Insurance Scheme among health workers in UNTH, Ituku-Ozalla, Enugu. The major sources of information of the respondents were colleagues, radios, televisions and seminars. It is important to note that these high levels of awareness have neither translated to high registration nor utilization levels among the respondents as not all the respondents were registered with the scheme. It is the opinion of the authors that the relatively low percentage of registered beneficiaries is due to misgivings of professionals in the healthcare delivery system about the workings of the NHIS. This apprehension is even more apparent among the professionals who should be more knowledgeable as majority of the doctors and nurses who had heard about the 
scheme were not registered. Even though most of the respondents think the scheme is inexpensive, quite a significant number are of the opinion that there are still some hidden charges in the scheme. This is of course as a result of poor enlightenment and misinformation concerning the operational guidelines of the scheme. Most of our respondents noted bureaucracy, unavailability of expensive drugs and long queues as problems encountered while using the scheme.

\section{Recommendations}

Based on the research findings, the following are recommended:

1) More enlightenment on the guidelines for membership, coverage and benefit packages of the NHIS.

2) Encouraging the younger age groups and the singles to invest in the future as regards their health insurance.

3) Improved service delivery to reduce encumbrances faced by users of the scheme especially as regards unnecessary bureaucracy, long queues and unfriendly staff.

4) Wider coverage of the scheme and broadening of the scope of the scheme to include more expensive drugs and procedures.

5) Reduction in the percent charges should be considered in order to make it affordable.

\section{Acknowledgements}

We thank the Lord Almighty for his sustenance and guidance without which the effort put into this work would have been in vain. We greatly appreciate our supervisor, Professor B.S.C Uzochukwu who gave us much support and direction at every stage of this work. We acknowledge our families for their moral and financial support, also to our friends and loved ones, and to all our respondents for sparing their time to answer our questions.

May God abundantly bless you all.

\section{References}

[1] Implementation of United Nations Millennium Declaration: Report of the Secretary-General. Department of Millennium Development Goals, Health and Policy Development. Geneva. 2002. www.who.int/mdg.

[2] Dogo-Muhammad M.B.W mni. The National Health Conference. Achieving the 4th and 5th MDGs in Nigeria: The NHIS-MDG MCH Project.

[3] Otoyemi O.D. Orthodontics in Nigeria: Journey So Far and Challenges Ahead. Journal of Orthodontics, 2008; 28: $90-92$.

[4] Sanusi R.A, Awe A.T. An Assessment of Awareness Level of National Health Insurance Scheme by Health Care Consumers in Oyo State, Nigeria. Medwell Journals, 2009: 144 - 145.

[5] Kutzin J. Health Insurance for the Formal Sector in Africa. WHO Geneva, 1997.

[6] Wikipedia; The Free Encyclopedia www.en.wikipedia.org/wiki/national.healthinsurance

[7] WHO/Migration of Health Workers. www.who.int/mediacentre/factsheet/index.html

[8] National Health Insurance Scheme Operational Guidelines. October 2007: 7- 10.

[9] Ezegwui E.C, Lecture on Maternal and Perinatal morbidity and mortality. Senior Lecturer and Consultant, Department of Obstetrics and Gynaecology. University of Nigeria Teaching Hospital, Ituku Ozalla, Enugu State, Nigeria.

[10] www.motherlandnigeriahealthcare.html 
[11] Okaro A.O, Ohagwu C.C, Njoku J. Awareness and Perception of National Health Insurance Scheme Among Radiographers in SouthEast Nigeria, American Journal of Scientific Research, 2010; 8: 21.

[12] Adeniyi A.A, Onajole A.T. The National Health Insurance Scheme (NHIS): A Survey of Knowledge and Opinions of Nigerian Dentists in Lagos. PubMed, 2010.

[13] Olugbenga-Bello A.I, Adebimpe W.O. Knowledge and Attitude of Civil Servants in Osun State, Southwestern Nigeria towards the National Health Insurance. Niger J Clin Pract, 2010; 13: 421 426.

[14] Awosika L. Health Insurance and Managed Care in Nigeria. Annals of Ibadan Postgraduate Medicine, 2005; 3: 40.

[15] Health Insurance Report, Repositioning the National Health Insurance Scheme (NHIS) for Effective Take-off: From Policy to Action. A quarterly Health Insurance Journal, 2005. www.carenet.info/files/health_insurance_7.pdf

[16] Li-Mei C, Shi WW, Chung-Yi L. The Impact of National Health Insurance on the Utilization of Health Care Services by Pregnant Women: The Case in Taiwan. Maternal and Child Health Journal 2001; 5(1): 35-42.

[17] Ashton T. HealthCare Systems In Transition: New Zealand. Part 1: An Overview of New Zealand 'e s Health Care System. Journal of Public Health, 1996; 18: 269-273.

[18] Fukawa T. Public Health Insurance in Japan. Washington D.C.: The International Bank for Reconstruction and Development/The World Bank; 2002.

[19] Kerr E. Health Care System In Transition. Belgium: European Observatory on HealthCare Systems; 2000.

[20] Collins SR, White C, Kriss JL. Whither Employer Based Health Insurance? The Current And Future Role of United States Companies in The Provision And Financing Of Health Insurance. The Commonwealth Fund Publication Number 1059; 2007.

[21] www.photius.com/rankings/healthranks.html

[22] Ibiwoye A, Adeleke I.A. A Log-Linear Analysis of Factors Affecting the Usage of Nigeria"s National Health Insurance Scheme. Medwell Journals, 2009: 588, 590.

[23] Osoka O. Insurance and Nigerian Economy. Lagos; Panache publication 1992.

[24] Schiffmann L.G and Kanuk L.S. Consumer Behavior. 7th edition. New Jersey: Prentice-Hall Inc, 2000.

[25] Yusuf T.O, Gbadamosi A, Hamadu D. Attitudes of Nigerians towards Insurance Services: An Empirical Study. African Journal of Accounting, Economics, Finance and Banking Research, 2009; 4: 35, 42 .

[26] Agba, Ogaboh A.M, Ushie E.M, Osuchukwu N.C. National Health Insurance Scheme and Employeese Access to Healthcare Services in Cross-River State, Nigeria. Global Journal of Human Social Science, 2010; 10(7): 14.

[27] Ibiwoye A. Adeleke I.A. Does National Health Insurance Promote Access to Quality Health Care? Evidence from Nigeria. Palgrave Journals, 2008; 33: 16, 226.

[28] National Health Insurance Scheme (NHIS) Ministerial Expert Committee set up by Honourable Minister of Health, Prof Eyitayo Lambo: Final Draft. 2003: 13 \& 14.

[29] Uzochukwu B.S.C. Guide for preparing a research proposal. Consultant and Senior Lecturer, Department of Community Medicine, University of Nigeria, Enugu Campus.

[30] Onwasigwe C. Medical Research Project: A Practical Guide. 1st edition. Enugu. El,„Demark (Publishers) 2004: 104, 105, 124.

[31] www.unthenugu.org/centre_services.html

[32] www.unthenugu.org/index.html

\footnotetext{
*Corresponding author.

E-mail address: celesmeka@yahoo.com
} 